\title{
DEIKSIS DALAM NOVEL "RAHWANA" KARYA ANAND NEELAKANTAN
}

\author{
Ahmad Dedi Mutiadi, Dian Aulia Respati \\ Pendidikan Bahasa dan Sastra Indonesia \\ Fakultas Keguruan dan Ilmu Pendidikan Universitas Kuningan \\ Jl. Cut Nyak Dien No. 362 Kuningan Telpn./Fax. (0232) 874824 \\ ahmad.dedi.mutiadi@uniku.ac.id \\ dianauliarespati@gmail.com
}

\begin{abstract}
ABSTRAK: Penelitian ini bertujuan mengungkap penggunaan deiksis persona, tempat, waktu, wacana, dan sosial dalam novel Rahwana karya Anand Neelakantan. Metode penelitian yang digunakan dalam penelitian ini adalah metode penelitian kualitatif. Teknik Pemerolehan data dengan menggunakan studi pustaka/dokumentasi. Objek Penelitian dalam penelitian ini adalah deiksis dalam novel Rahwana karya Anand Neelakantan. Hasil penelitian ini adalah sebagai berikut: 1) deiksis persona menyebabkan tokohtokoh dalam novel Rahwana berpindah-pindah peran menjadi pembicara seperti aku, kita, dan kami. Peran menjadi lawan bicara atau yang diajak bicara seperti kau dan kalian. Peran menjadi yang dibicarakan seperti dia dan mereka. 2) Deiksis tempat menyebabkan rujukan tempat berpindah-pindah jaraknya berdasarkan peristiwa bahasa dan konteksnya 3) Deiksis waktu dapat menyebabkan rentang waktu berpindah-pindah rujukannya. 4) Deiksis wacana dapat menyebabkan rujukan dapat berpindahpindahnya keterangan dari rujukan dalam bentuk sebelum atau bisa menjadi setelahnya 5) Deiksis sosial dapat menyebabkan perbedaan tingkatan seseorang, seperti jabatan atau kasta yang berubah-ubah berdasarkan pelaku peristiwa bahasa dan konteksnya.
\end{abstract}

KATA KUNCI: Analisis deiksis persona, deiksis tempat, deiksis waktu, deiksis wacana, dan deiksis sosial.

\begin{abstract}
This study aims to reveal the use of persona, place, time, discourse, and social deixis in Rahwana's novel by Anand Neelakantan. The research method used in this study is a qualitative research method. Data acquisition techniques using literature study / documentation. The object of research in this study is deixis in the novel Rahwana by Anand Neelakantan. The results of this study are as follows: 1) Deixis persona causes the characters in Rahwana's novel to move into the role of speakers like me, us, and us. The role of being the person you're talking to or being talked to as you and you are. The role of being talked about like him and them. 2) Deixis of place causes a reference to a place to move its distance based on language events and context 3) Deixis of time can cause a span of time to move its reference. 4) Deiksis discourse can cause references can move information from references in the form before or can become after 5) Social deixis can cause differences in a person's level, such as position or caste that changes based on the perpetrators of language events and context.
\end{abstract}

KEY WORDS: Analysis deixis persona, deixis place, deixis time, deixis of discours, and deixis social

\section{PENDAHULUAN}

Dalam kehidupan manusia, bahasa digunakan dalam segala aktivitas. Keunikan manusia bukan hanya terletak pada kemampuan berpikirnya saja melainkan juga terletak pada kemampuannya berbahasa. Tanpa kemampuan berbahasa ini maka manusia tak mungkin mengembangkan kebudayaannya, sebab tanpa mempunyai bahasa maka akan hilang pula kemampuan untuk meneruskan nilai-nilai budaya dari generasi yang satu ke generasi selanjutnya.

Bahasa merupakan hal yang hakiki dalam kehidupan manusia. Dengan bahasa manusia dapat berkomunikasi dengan manusia lainnya. Mempelajari bahasa dan mengkaji bahasa merupakan hal paling penting dilakukan oleh manusia karena secara langsung akan melestarikan dan menginvestariskan bahasa tersebut. Adapun yang menjadi kajian dalam 
bahasa meliputi sintaksis, semantik, pragmatik, dan masih banyak lagi.

Dalam pemakaian bahasa terkadang kita harus mengerti maksud dan menggunakan bahasa yang tepat dalam berbagai situasi. Kajian bahasa yang mempelajari hal-hal seperti itu dinamakan Pragmatik.

Menurut George Yule (2006, hlm. 3), pragmatik merupakan studi tentang makna yang disampaikan oleh seorang penutur (penulis) dan ditafsirkan oleh seorang pendengar atau pembaca atau pembaca. Sebagai akibatnya studi ini lebih banyak berhubungan dengan analisis tentang apa yang dimaksud orang dengan tuturan-tuturannya, daripada dengan makna yang digunakan dalam tuturan itu sendiri. Dengan demikian pragmatik disebut sebagai studi tentang maksud penutur. Adapun yang menjadi kajian dari pragmatik yaitu deiksis, implikatur, presuposisi, tindak tutur, dan aspek-aspek struktur wacana. Dalam penelitian ini peneliti akan membahas salah satu dari bidang kajian pragmatik tersebut yaitu deiksis.

Sebuah bentuk bahasa dikatakan deiksis apabila acuan atau referennya berpindah-pindah bergantung pada siapa yang menjadi pembicara dan bergantung pula pada saat dan tempat dituturkannya kata itu. Misalnya kata saya, sini, sekarang (Purwo, 1984, hlm. 10). Demi pengertian penuh istilah "deiksis" itu, perlu diperhatikan bahwa unsur-unsur yang mengandung arti (biasanya: leksem (lexeme); tetapi juga yang menggantikannya secara pronominal, baik itu berupa bentuk bebas maupun bentuk yang terikat secara morfemis) dapat dibedakan antara yang referensial (misalnya kata rumah, meja) dan yang tidak referensial (misalnya kata walaupun, aduh).

Peristiwa deiksis merupakan cara yang paling jelas untuk menggambarkan hubungan antara bahasa dan konteks dalam berbahasa. Deiksis dibagi menjadi enam jenis yaitu deiksis persona, deiksis tempat, deiksis waktu, deiksis penunjuk, deiksis wacana, dan deiksis sosial. Deiksis persona menunjuk kepada peran dari partisipan dalam peristiwa percakapan misalnya pembicara, yang dibicarakan, dan identitas yang lain. Deiksis tempat berkaitan dengan spesifikasi tempat relatif ke titik labuh dalam peristiwa tutur. Deiksis waktu merupakan pengungkapan kepada titik atau jarak waktu dipandang dari saat suatu ujaran terjadi, atau pada saat seorang penutur berujar. Deiksis penunjuk, di dalam bahasa Indonesia sesuatu yang dekat dengan penutur, dan itu untuk menunjuk sesuatu yang jauh dari pembicara. Deiksis wacana mengacu pada bagian-bagian tertentu dalam wacana yang telah diperikan (sebelumnya) dan atau yang sedang dikembangkan. Deiksis sosial berhubungan dengan aspek-aspek kalimat yang mencerminkan kenyataankenyataan tertentu tentang situasi sosial ketika tindak tutur terjadi.

Penelitian deiksis ini dipilih karena masih belum banyak penelitian mengenai deiksis ini. Ternyata dengan mengetahui deiksis kita akan lebih mudah untuk memahami maksud dan tujuan dari komunikasi. Deiksis juga dipilih karena deiksis mampu memperlihatkan secara jelas peran-peran yang ditunjukan oleh penggunaan bahasa.

Dalam kehidupan sehari-hari sering kali kita menjumpai penggunaan deiksis dalam berbagai hal, misalnya dalam percakapan, surat kabar, dan dalam karya-karya fiksi. Salah satunya dapat dilihat dalam karya fiksi yaitu novel. Novel sering dikatakan sebagai karangan yang menceritakan suatu peristiwa yang luar biasa dalam kehidupan manusia. Dikatakan luar biasa sebab hanya memuat cerita berdasarkan konflik hidup yang sangat menonjol sehingga menceritakan tokoh sejak kecil sampai dewasa dianggap tidak perlu. Konflik batin yang mendalam 
dari para tokoh menjadi sasaran utama cerita, hal itu menyebabkan plot menjadi erat, tunggal dan menarik. Novel dapat dikatakan sebagai proses rekaan yang panjang yang menyuguhkan tokoh-tokoh dan menampilkan serangkaian peristiwa dan latar secara tersusun (Panuti Sudjiman, dalam Aan Sugiantomas, 2016, hlm. 51).

Untuk itu, cara untuk menggambarkan hubungan antara tokohtokoh, peristiwa, dan konteks dalam novel digunakan ilmu bahasa yaitu deiksis. Dengan menggunakan deiksis maka kita akan memahami serangkaian peristiwa dalam novel.

Novel yang diteliti adalah novel Rahwana karya Anand Neelakantan. Novel pewayangan yang bercerita mengenai kisah Ramayana dari sudut pandang tokoh yang kalah, yaitu Rahwana. "Aku menulis dengan sudut pandang orang pertama untuk menelusuri ceruk-ceruk terdalam pikiran Rahwana untuk menyingkap lipatan-lipatan emosi Rahwana. Tapi aku pun memperkenalkan sosok lain: Bhadra, abdi Rahwana. Aku menghidupkan sosoknya yang sangat kritis pada junjungannya agar tulisanku tidak jatuh menjadi sastrapuja yang hanya mengagul-agulkan Rahwana. Tak ada penjahat atau pahlawan dalam cerita ini. Yang ada hanya para korban keadaan, manusia-manusia yang terperangkap dalam jaring masyarakat dan waktu". Sebuah pernyataan dari Anand Neelakantan mengenai novel ini menggambarkan bahwa terdapat berbagai tokoh, tempat, waktu dan kasta sosial yang menjadi alasan peneliti menjadikan novel Rahwana sebagai objek penelitian untuk diteliti menggunakan deiksis. Dalam novel tersebut terdapat banyak tokoh serta memiliki konteks dan situasi yang memungkinkan terjadinya deiksis.

Berdasarkan latar belakang masalah yang dikemukakan di atas maka tujuan dalam penelitian ini adalah
Mendeskripsikan deiksis dalam novel Rahwana karya Anand Neelakantan.

\section{METODE PENELITIAN}

Penelitian ini menggunakan metode deskriptif kualitatif. Penelitian kualitatif selalu bersifat deskriptif, artinya data yang dianalisis dan hasil analisisnya berbentuk deskriptif fenomena. Metode kualitatif memberikan perhatian terhadap data ilmiah, data dalam hubunganya dengan konteks keberadaanya.

Teknik penelitian yang digunakan peneliti ini terbagi menjadi dua bagian yaitu pemerolehan data dan pengolahan data.

\section{Teknik Pemerolehan data}

Teknik yang akan digunakan untuk mengumpulkan data dalam penelitian ini adalah teknik dokumentasi. Adapun teknik pengumpulan data dalam penelitian ini sebagai berikut:

1. Membaca keseluruhan novel Rahwana karya Anand Neelakantan secara berulang-ulang untuk mengidentifikasi jenis-jenis deiksis yang terdapat dalam novel.

2. Memberi tanda (menggaris bawahi) bagian kata atau kalimat dalam novel Rahwana karya Anand Neelakantan yang berhubungan dengan jenis-jenis deiksis.

3. Memasukan semua kata atau kalimat yang berkaitan dengan deiksis yang ada pada novel Rahwana karya Anand Neelakantan ke dalam tabel.

\section{Teknik Pengolahan Data}

1. Mengidentifikasi bentuk bahasa yang mengandung deiksis persona, tempat, waktu, wacana, dan sosial dalam novel Rahwana karya Anand Neelakantan.

2. Mencari konteks pada data deiksis yang terdapat dalam novel Rahwana karya Anand Neelakantan. 
3. Menganalisis data deiksis persona, tempat, waktu, wacana, dan sosial dalam novel Rahwana karya Anand Neelakantan.

4. Menyimpulkan hasil analisis data.

\section{HASIL DAN PEMBAHASAN}

Berdasarkan hasil analisis dan pengolahan data tentang Deiksis dalam novel Rahwana karya Anand Neelakantan dapat disimpulkan sebagai berikut.

Deiksis persona, tempat, waktu, wacana, dan sosial yang terdiri dari 137 deiksis persona, 30 deiksis tempat, 18 deiksis waktu, 27 deiksis wacana, dan 8 deiksis sosial. Lima deiksis ini menyebabkan rujukan dapat berpindahpindah berdasarkan peran dan konteks cerita. Lima deiksis ini disimpulkan sebagai berikut.

1. Deiksis persona menyebabkan tokohtokoh dalam novel Rahwana berpindah-pindah peran menjadi pembicara seperti aku, kita, dan kami. Peran menjadi lawan bicara atau yang diajak bicara seperti kau dan kalian. Peran menjadi yang dibicarakan seperti dia dan mereka.

2. Deiksis tempat menyebabkan rujukan tempat berpindah-pindah jaraknya menjadi di sini dan di sana berdasarkan pelaku dalam peristiwa bahasa dan konteksnya.

3. Deiksis waktu dapat menyebabkan rentang waktu berpindah-pindah rujukannya berdasarkan konteks dan situasi saat terjadinya peristiwa bahasa.

4. Deiksis wacana dapat menyebabkan rujukan dapat berpindah-pindahnya keterangan dari rujukan dalam bentuk sebelum atau bisa menjadi setelahnya.

5. Deiksis sosial dapat menyebabkan perbedaan tingkatan seseorang, seperti jabatan atau kasta yang berubah-ubah berdasarkan pelaku peristiwa bahasa dan konteksnya.

\section{DAFTAR PUSTAKA}

Chaer, Abdul. 2012. Linguistik Umum. Jakarta: Rineka Cipta.

Dwi, Hendro. 2002. Deiksis dalam Bahasa Besemah. Yogyakarta: Deepublish.

Lancana, A Paola. 2017. Jurnal Bastra. Deiksis dalam Novel Tembang Ilalang Karya Md. Aminudin A. Paola Lancana Aminuddin.3(3): 35.

Leo, Heppy. 2012. Students e-jurnal. Analisis Deiksis Persona dalam Ujaran Rusia (Suatu Tinjauan Pragmatik).1(1): 4.

Mekarwaty, Sriyulan. 2014. Deiksis dalam Novel Yang Miskin Dilarang Maling. Gorontalo: Universitas Negeri Gorontalo.

Moeliono, Anton. 1997. Santun Bahasa. Jakarta: Gramedia Pustaka Utama.

Nababan. 1987. Sosiolinguistik. Jakarta: Gramedia Pustaka Utama.

Nasution, Bakhtaruddin. 2012. Deiksis Sosial Dalam Novel Negeri 5 Menara Karya A. Fuadi (Suatu Tinjauan Pragmatik). 1(1): 84-91.

Neelakantan, Anand. 2017. Rahwana. Tanggerang: PT Kaurama Buana Antara.

Purwo, Bambang Kaswanti. 1984. Deiksis dalam Bahasa Indonesia. Jakarta: Balai Pustaka.

Rahardi, Kunjana. 2005. Pragmatik. Jakarta: Erlangga.

Sugianto Mas, Aan. 2015. Langkah Awal Menuju Apresiasi Sastra Indonesia. Kuningan: Pendidikan Bahasa dan Sastra Indonesia FKIP Uniku.

Sugianto Mas, Aan. 2016. Kajian Prosa Fiksi \& Drama. Kuningan: Pendidikan Bahasa dan Sastra Indonesia FKIP Uniku.

Sugiyono. 2016. Metode Penelitian Pendidikan. Bandung: Alfabeta.

Tologana, Walset. 2017. Jurnal elektronik Fakultas Sastra Universitas Sam 
FON : Jurnal Pendidikan Bahasa dan Sastra Indonesia

Volume 14 Nomor 1 Tahun 2019

Ratulangi. Deiksis dalam Novel Assalamualaikum Beijing karya Asma Nadia (Suatu Kajian

Yule, George. 2006. Pragmatik. Pragmatik). 4(6): 1-4.

Yogyakarta: Pustaka Pelajar. 